\title{
Kültürel Miras Eğitimi Açısından Turizm Rehberliği Bölümlerine Yönelik Müfredat İncelemesi
}

\section{Examination on the Curriculum of Tourism Guidance Departments within the Scope of Cultural Heritage Education}

\author{
Arș. Gör. Aybüke ÖZSOY \\ Nevşehir Hac1 Bektaş Veli Üniversitesi, Turizm Fakültesi, Türkiye \\ Nevsehir Haci Bektas Veli University, Faculty of Tourism, Turkey \\ E-Mail: aybuke.ozsoy@nevsehir.edu.tr
}

Arş. Gör. Dr. Zeynep ÇOKAL Nevşehir Hacı Bektaş Veli Üniversitesi, Turizm Fakültesi, Türkiye Nevsehir Haci Bektas Veli University, Faculty of Tourism, Turkey E-Mail: zeynepkabaoglu@ @evsehir.edu.tr

$\ddot{O} z$

Amaç ve Önem: Turist rehberleri ülkelerinin kültür elçisi konumunda, turistle birebir iletişimde olan kişilerdir. Bunun yanı sıra destinasyon imajının oluşmasında önemli bir görev üstlenmektedir. Bu görevi de turiste destinasyondaki doğal kültürel miras alanlarının tanıtımını yaparak yerine getirmektedir. Tanıtımın en iyi şekilde yapılabilmesinde turist rehberlerinin miras kavramına ilişkin bilgi düzeyleri oldukça önemlidir. Kültürel miras kapsamında gerek somut gerekse somut olmayan miras unsurları ele alınmaktadır. $\mathrm{Bu}$ miras unsurlarına ilişkin turist rehberlerine eğitim verilmesi konusunda ise yükseköğretim kurumlarının turist rehberi yetiştiren bölümlerine oldukça önemli bir sorumluluk düşmektedir.

Yöntem: Çalışma kapsamında lisans düzeyinde 38 adet "turizm rehberliği/ seyahat işletmeciliği ve turizm rehberliği" programının müfredatları "kültürel miras" dersi kapsamında incelenmiştir. Araştırmada ikincil verilerden faydalanarak doküman incelemesi yapılımıştır. Veriler lisans düzeyinde turizm rehberliği eğitimi veren devlet ve vakıf üniversitelerinin internet sayfaları aracılığı ile elde edilmiştir.

Bulgular: Kültürel miras eğitimi kapsamında incelenen müfredatların yarısında $(\% 47,37)$ kültürel mirasa ilişkin ders olmadığ 1 tespit edilmiştir. Bununla birlikte kültürel mirasa ilişkin derslerin müfredatlarda yeterli sayıda ve saatte olmadığı, müfredatlar arasında uyum olmadığı ve her kurumun kendine göre farklı bir isimle dersi adlandırdığı bulgusuna ulaşılmıştır.

Özgünlük/Bilimsel Katkı: Çalışmada, kendine özgü yaklaşım ve parametreler kapsamında turist rehberliği eğitiminde kültürel miras eğitiminin yeri ve önemi ortaya konulmaya çalışılmıştır. Turist rehberliği eğitimi ile ilgili çalışmalara bütünsel bir bakış ile yol gösterici nitelikte bilgiler sunulmaktadır.

Sınırlııklar: Çalışma kapsamında lisans düzeyinde turizm rehberliği eğitimi veren kurumların müfredatları incelenmiştir. Müfredatlarına ulaşılamayan yükseköğretim kurumları olması nedeniyle buradan elde edilen sonuçlar ile tüme varıma gidilmişsir. Bu kapsamda yükseköğretim kurumlarından müfredatlarına ulaşılabilenler ile çalışmanın yapılması sınırlılıklar kapsamında değerlendirilebilir.

Anahtar Kelimeler: Kültürel miras, turist rehberliği, müfredat incelemesi.

Makale Türü: Araştırma makalesi

Atıf için (for cited); Özsoy, A. ve Çokal, Z. (2021). Kültürel Miras Eğitimi Açısından Turizm Rehberliği Bölümlerine Yönelik Müfredat İncelemesi, Turist Rehberliği Dergisi, 4(2), 106-118. 
Turist Rehberliği Dergisi (TURED) \& Yıl. 2021, Cilt. 4, Sayı. 2

Journal of Tour Guiding (JOTOG) \& Year. 2021, Volume. 4, Issue. 2

\begin{abstract}
Purpose and Importance: Tourist guides are the cultural ambassadors of their countries and they are the people who are in direct contact with the tourists. In addition, it plays an important role in the formation of the destination image. They perform this task by promoting the natural cultural heritage sites in the destination to the tourist. The knowledge level of tourist guides on the concept of heritage is very important in order to make the best possible promotion. Within the scope of heritage, both tangible and intangible heritage elements are discussed. A very important responsibility falls on the departments of higher education institutions that train tourist guides in terms of training tourist guides regarding these heritage elements. In this context, this study aims to examine the education given on cultural heritage in programs that provide tourism guidance education at the undergraduate level.
\end{abstract}

Methodology: Within the scope of the study, the curricula of 38 undergraduate-level "tourism guidance/travel management and tourism guidance" programs were examined within the scope of the "cultural heritage" course. In the research, document analysis was carried out by making use of secondary data. The data were obtained through the websites of state universities and foundation universities that provide tourism guidance education at the undergraduate level.

Findings: It has been determined that half of the curricula $(47.37 \%)$ examined within the scope of cultural heritage education do not have courses related to cultural heritage. However, it has been found that the courses related to cultural heritage are not sufficient in number and time in the curricula, there is no harmony between the curricula, and each institution names the course with a different name according to its own.

Originality/Value: In the study, the place and importance of cultural heritage education in tourist guidance education has been tried to be revealed within the scope of its unique approach and parameters. Guiding information is presented with a holistic view to the studies on tourist guiding education.

Limitations/implications: Within the scope of the study, the curricula of institutions providing tourism guidance education at the undergraduate level were examined. Since there are higher education institutions whose curricula cannot be reached, induction has been made with the results obtained here. In this context, working with those who can access their curriculum from higher education institutions can be evaluated within the scope of limitations.

Keywords: Cultural heritage, tourist guidance, examination on the curriculum.

Paper Type: Research article

\title{
Giriş
}

Kültürel miras unsurları toplumların geçmişine 1şı tutan ve geleceğe kalmalarını sağlayan önemli değerler arasında yer almaktadır. Kültürel mirasın sürdürülebilirliği korunması ve aktarılması ile mümkün olmaktadır. Özellikle aktarım sürecinde toplumun her kesimine önemli roller düşmektedir. Toplumsal sorumluluğun yanı sıra bazı alanlarda kültürel mirasın korunması ve aktarılması için daha fazla özveri gerekmektedir. Kültürel mirasın aktarımında önemli rolü olan turist rehberliği mesleği turizm sektörü ele alındığında en fazla sorumluluğa sahip olan alanlardan biridir.

Turizm sektörünün önemli hizmet sağlayıcılarından biri olan turist rehberlerinin temel görevi destinasyonun tanıtımını yapmak ve olumlu bir imaj oluşturmaktır. Bu tanıtımı yaparken faydalandığ 1 en önemli kaynak ise kültürel miras unsurlarıdır. Kişiler farklı kültürleri tanıma ve deneyimleme isteği ile farklı destinasyonları ziyaret etmektedir. Bu deneyimlerini şekillendiren ve destinasyonun kültürel değerlerini onlara aktaran ise turist rehberleridir. $\mathrm{Bu}$ bağlamda turist rehberleri için kültürel miras bilgisi oldukça önemli olmaktadır. Bu da ancak iyi bir kültürel miras eğitimi ile mümkün olmaktadır.

Kültürel mirasın aktarımında bu kadar öneme sahip olan turist rehberlerinin almış olduğu kültürel miras eğitimi turist rehberliği eğitiminde önemli görülmektedir. Bu çalışma

Özsoy ve Çokal; Kültürel Miras Eğitimi Açısından Turizm Rehberliği Bölümlerine Yönelik Müfredat İncelemesi/ Examination on the Curriculum of Tourism Guidance Departments within the Scope of Cultural Heritage Education 
ile Türkiye'de lisans düzeyinde turizm rehberliği eğitimi veren kurumların müfredatları kültürel miras eğitimi açısından değerlendirilmektedir. Araştırma kapsamında müfredatlarda yer alan kültürel miras eğitimine ilişkin dersler belirlenmiş ve derslerin yeterli olup olmadığına yönelik tespitlerde bulunulmuştur.

\section{Turist Rehberliği Mesleği ve Ĕgitimi}

Turist rehberi, turizm alanındaki en önemli paydaşlarından biridir. Bu alandaki rolü, turistleri karşılamanın ve bilgilendirmenin çok ötesine geçmektedir. Bir destinasyona dair bilgi ve yorumları; bunun yanı sıra iletişim ve hizmet becerileri sayesinde rehberler, turist ziyaretlerini bir turdan daha çok bir deneyime dönüştürmektedirler (Ap \& Wong, 2001). Turist rehberleri, turistlerin tur boyunca deneyimlerinin artması aynı zamanda destinasyonların ve bölge kültürünün kavranması konusunda hayati bir rol oynamaktadır (Gelbman \& Maoz, 2012). Turistlere, cazibe merkezlerinde neleri gözlemleyip nelere dikkat etmeleri gerektiğini ve daha da önemlisi, gördüklerini nasıl yorumlayacaklarını söyleyerek bakış açılarını yönlendirir (Urry, 1990).

Tarihin ilk çağlarından beri var olan turist rehberliğinin dünyada bir meslek olarak kabul görmesi, oldukça yeni bir tarihe dayanmaktadır (Albrecht et al., 2021). Türkiye'de ise çok daha yeni olan bu durum ilgili yasal düzenlemeler ile birlikte gerçekleşmiştir. 2012 yılında çıan 6326 sayılı Turist Rehberliği Meslek Kanunu ile rehberlik bir mesleki statüye kavuşmuş ve rehber sayılarında belirgin artışlar gözlenmiştir. 2021 yılı itibari ile turist rehberi sayısı 11520'dir (TUREB, 2021) ve bu meslek grubu nitelikli, çoğunlukla lisans mezunu, dil bilen ve Türkiye'yi en iyi şekilde tanıtabilecek eğitime sahip kişilerden oluşmaktadır.

Turizm olgusu içerisinden büyük pay alan turist rehberliğinin, turist deneyimine olan katkısı diğer turizm ile alakalı meslek gruplarına kıyasla fark edilir bir şekilde gelişme göstermiştir (FEG, 2021). Son zamanlarda rehberler için profesyonelleşme, resmi eğitim ve sertifikalandırma konularına daha fazla ilgi gösterilmektedir (Lugosi \& Bray, 2008). Örgün eğitim genellikle arzu edilen bir yol olarak görülmekte ve ilgili tartışmalar, çoğunlukla resmi eğitim programlarının geliştirilmesi için iyileştirilmiş hizmet kalitesi ve etkililiğine duyulan ihtiyacı belirtmektedir (Greiner \& Wegner, 2014). Ayrıca alanyazın, bu programların nasıl tasarlanması gerektiğine ve neleri içermesi gerektiğine de odaklanmaktadır.

1980'li yıllar ile birlikte Türkiye turizm sektöründe yaşanan olumlu gelişmeler neticesinde ülkeye yönelik turizm talebinde önemli artışlar yaşanmaya başlanmıştır. Bu artışla birlikte sektörde görev yapacak kişilerin gerekli niteliklere sahip olabilmeleri için belirli bir eğitim almaları da kaçınılmaz hale gelmiştir. Bu amaçla farklı düzeylerde örgün turizm eğitim bölümleri açılmaya başlanmıştır (Kuşluvan \& Çeşmeci, 2002).

Türkiye'de turist rehberliği eğitimi örgün ve yaygın olmak üzere iki şekilde verilmektedir. Örgün eğitim, üniversitelere bağlı olarak ön lisans, lisans, yüksek lisans ve doktora şeklinde verilmekte ve bu eğitim sonucunda öğrenciler diploma almaktadır, yaygın eğitim ise Turist Rehberleri Birliği (TUREB)'nin açtığ 1 kurslarla verilmekte olup, eğitime katılanlar bu kurslar sonucunda sertifika almaktadır (TUREB, 2021).

Bilgisi, becerisi, kültürü, tutum ve davranışları ile Türkiye ve Türk insanını temsil edecek ve doğru tanitacak, ziyaretçilerin memnun ve olumlu izlenimlerle ülkelerine geri dönmelerini sağlayacak, nitelikli turist rehberlerinin eğitimi hassas ve ciddi biçimde ele alınması gereken bir konudur (Kuşluvan \& Çeşmeci, 2002). İyi bir rehberlik eğitimi, kaliteli rehberler yetişmesine, kaliteli rehberlerin eşlik ettikleri grubun ziyaretlerinden memnun kalmasına, tatillerinden mutlu ayrılan turistler olumlu ülke imajına, bir ülkenin turizmdeki imajının olumlu yönde gelişmesi turizmden aldığı payın artmasına ve dolayısıyla rekabet 
Turist Rehberliği Dergisi (TURED) \& Yıl. 2021, Cilt. 4, Sayı. 2

Journal of Tour Guiding (JOTOG) \& Year. 2021, Volume. 4, Issue. 2

üstünlüğü elde etmesine imkân tanıyacaktır (Eker \& Zengin, 2016). Birer kültür elçisi olan turist rehberleri kültürel mirasın korunması, yaşatılması ve aktarılmasında da kilit rol üstlenmektedir (Köroğlu vd., 2018). Bütün bunlar şüphesiz iyi bir turist rehberliği eğitimi sayesinde gerçekleşebilmektedir. Türkiye'de yükseköğretim düzeyinde, örgün turizm rehberliği eğitiminin önemli bileşenlerinden biri ön lisans, lisans, yüksek lisans ve doktora turizm rehberliği programlarıdır.

Tablo 1

Ĕgitim Derecesine Göre Turist Rehberliği Eğitiminin Verildiği Üniversiteler

\begin{tabular}{|c|c|c|}
\hline Ön Lisans Eğitimi & Lisans Eğitimi & Lisans Üstü Eğitim \\
\hline 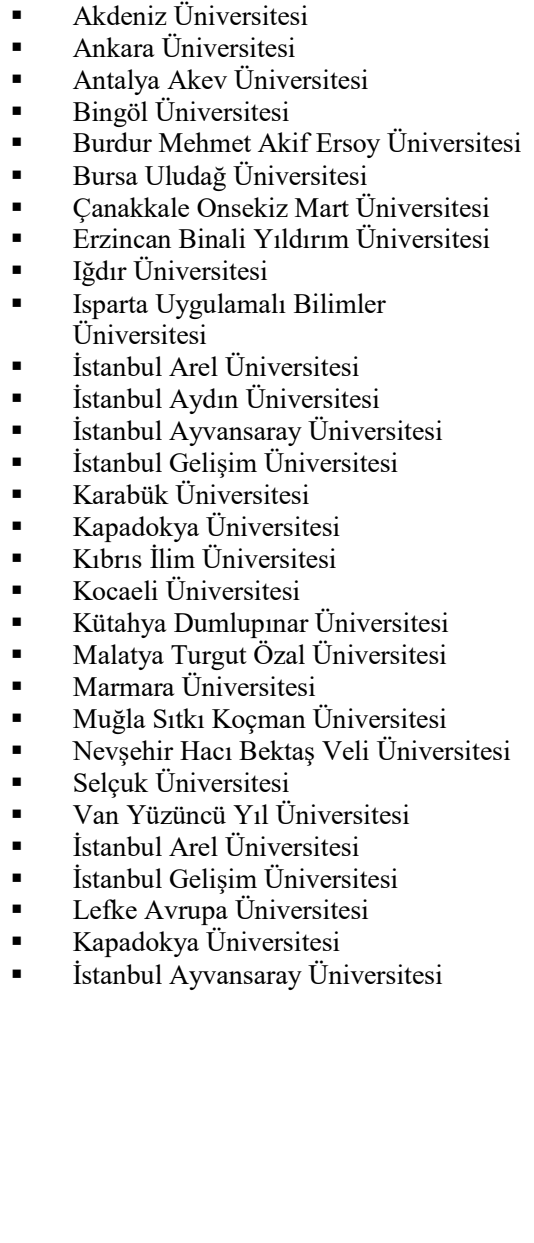 & 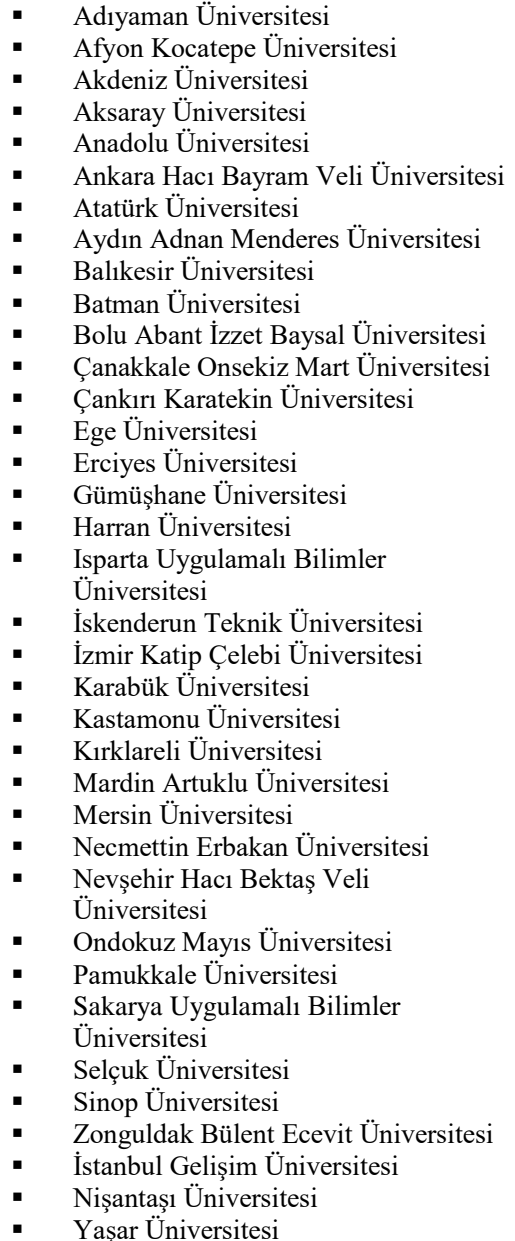 & 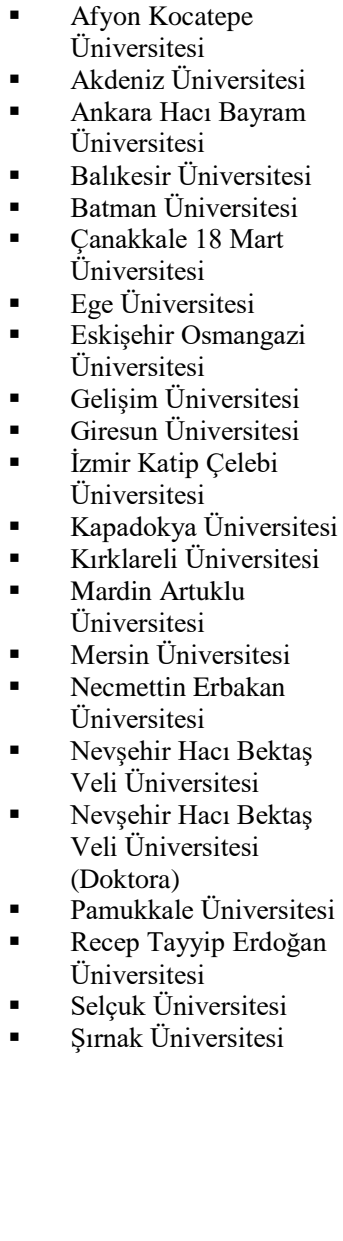 \\
\hline
\end{tabular}

Kaynak: YÖK Lisans Atlası, 2021

Tablo 1'de yer verilen bilgilere göre Türkiye'de “turizm rehberliği / seyahat işletmeciliği ve turizm rehberliği" programları çatısı altında eğitim öğretim faaliyetlerine devam eden bölümlerin sayıs1 30'u ön lisans, 36's1 lisans, 20'si yüksek lisans ve 1 doktora olmak üzere toplamda 87 'dır. Bunların ön lisans düzeyinde 25 'i devlet, 5 'i vakıf, lisans düzeyinde 33'ü devlet, 3'ü vakıf, yüksek lisans düzeyinde18'i devlet 2'si vakıf üniversitelerinde bulunmaktadır. Doktora düzeyinde ise Nevşehir Hacı Bektaş Veli Üniversitesi, Turizm Araştırmaları Enstitüsü bünyesinde 1 adet program bulunmaktadır. 


\section{Kültürel Miras ve Turist Rehberliği İlișkisi}

Kültür, doğası gereği sürekli değişim içindedir ve toplumun koşullarına göre biçimlenerek devir daim eder. Miras kavramı ise bugünden çok geçmişi konu edinir. Aralarındaki zaman zıtlığına rağmen kültür ve miras sürekli birlikte anılan kavramlardır (Ölçer \& Özünel, 2013). Kültürel miras; geçmiş, günümüz ve gelecekte var olacak toplum yapılarının kaynă̆ını oluşturmaktadır (Nişancı, 2012). Kültür ve kültürel miras toplumların temelidir ve bu bağlamda kültürü ifade eden yapıtlar, gelecek kuşaklara bu eserlerin ortaya çıkış zamanlarını gösteren şahitler olarak ifade edilmektedir (Köroğlu vd., 2018).

Zaman içinde kültürel miras kavramı ile ilgili birçok fikir ortaya atılmış fakat bu kavramlar sürekli değişmiştir. Son olarak 2006 yılında Avrupa Konseyi’nin mevzuatına eklediği Toplum için Kültürel Mirasın Değeri Çerçeve Sözleşmesi (Faro Sözleşmesi)'nin ikinci maddesinde kültürel miras üzerine yeni bir tanım ortaya konmuş ve "kültürel miras, geçmişten devralınan, insanların, sürekli evrilen değer, inanç, bilgi ve geleneklerinin anonim bir ifadesi ve yansıması olarak ayırt ettikleri bir kaynaklar kümesi..." şeklinde ifade edilmiştir. Bu tanımın yanı sıra, ilgili sözleşmenin dördüncü maddesinde insanların ve toplulukların, kültürel mirastan yararlanmasına ve zenginleşmesine katkı sağlamaya hakkı olduğu ve insanların, diğerlerinin kültürel mirasına saygı göstermesi gerektiği vurgulanmıştır (Şimşek, 2014). Kültür ve Turizm Bakanlığı ise kültürel mirası, "geçmişten miras alınan ve farklı nedenlerle geleceğe miras bırakılmak istenen, fiziksel olarak var olan ve insanlar tarafindan yapılmış her türlü eserler ile bir topluma ait değerler bütünü” şeklinde tanımlanmaktadır (KTB, 2009). UNESCO Dünya Kültürel ve Doğal Mirasının Korunmasına Dair Sözleşme kapsamında Türkiye'de 2021 y1lı itibari ile 19 adet Somut Kültürel Miras ögesi bulunurken 20 adet de Somut Olmayan Kültürel Miras ögesi bulunmaktadır (KTB, 2021).

Kültür ile iç içe olan turizm, kültür varlıklarının korunması anlamında önemlidir. Diğer yandan kültürel miras ögelerinin turistik ürün olarak öne sürülmesi bu önemli değerlerin zarar görmesine, dejenere olmasına, benliğini kaybetmesine neden olabilmektedir. $\mathrm{Bu}$ olumsuz sonuçların azaltılması veya önüne geçilebilmesi için turizmin çevresel, kültürel etkileri hakkında bilgi ve deneyim kazanmak gerekmektedir (Demir vd., 2018).

Turistik bölgeleri ziyaret eden insanların en fazla etkileşim halinde olduğu kişi turist rehberidir (Ap \& Wong, 2001). Turist rehberleri kültürel mirası turistlere ileten bir elçi olarak bir kültürden diğerine bilgiyi ve deneyimi aktarabilme ve etkin bir biçimde iletişim kurabilme açısından da oldukça önemli bir role sahiptir (Tekin vd., 2015).

Alanyazında turist rehberlerinin rolleri için Leclerc \& Martin (2004) ve Reisinger \& Steiner (2006) tarafından kültür simsarı, aracı ve yorumcu ifadeleri kullanılırken, Cohen'e göre (1985) kültür elçisi ifadesi kullanılmaktadır. Kültür elçiliği profesyonel turist rehberlerinin başlıca rolüdür (Yu \& Ham, 2004) ve genellikle merak uyandıran düşünceleri aktarmayı ve ev sahibi toplum ile turist arasında bağ kurmaya yardımcı olan öncelikli roldür (Cohen, 1985). Turist rehberleri üstlendikleri bu kültürel görev neticesinde kültürü koruma ve yaşatma gayesi içerisinde mesleklerini icra etmekle yükümlüdür (Ar \& Çelik Uğuz, 2015). Turist rehberi adaylarının da meslek bilincine sahip, kültürel mirasın öneminin farkında olmaları ve üstlenecekleri görevleri başarı ile yerine getirmeleri beklenmektedir.

Eğitim ile toplumlar daha doğru kararlar almakta ve bu kararları hayata geçirmeye yönelmektedir (Özkök \& Gümüş, 2009). Kültürel miras açısından eğitim, nesiller arasında kültür aktarımı esnasında miras değerlerinin önemini vurgulamaya, kültürel yozlaşmaya karşı bireysel rol ve görevlerin kazanılmasına, dolayısıyla da kültürel mirası sürdürmeye ve korumaya yardımcı olur (Demir vd., 2018). Bu konudaki gerekli eğitimin sağlanması, kişininin

Özsoy ve Çokal; Kültürel Miras Eğitimi Açısından Turizm Rehberliği Bölümlerine Yönelik Müfredat İncelemesi/ Examination on the Curriculum of Tourism Guidance Departments within the Scope of Cultural Heritage Education 


\section{IIIII)}

Turist Rehberliği Dergisi (TURED) \& Yıl. 2021, Cilt. 4, Sayı. 2

Journal of Tour Guiding (JOTOG) \& Year. 2021, Volume. 4, Issue. 2

doğal, sosyal ve kültürel çevre üzerindeki olumsuz etkilerini azaltması ve bu değerlerin korunması açısından önem taşımaktadır (Kuter \& Ünal, 2009).

Eğitim yoluyla mirasın korunması, alanyazında son zamanlarda yaygın bir ilgi görmektedir. Eğitim, toplumsal mirasın korunması bilincini oluşturarak bunu daha yaygın kitlelere iletmek için kullanılan resmi bir mekanizma olarak düşünülebilir. Kültürel miras eğitimi, kültürel unsurları, miras aracılığıyla tarihi ve yaşanan kültürü anlamayı hedefleyen bir öğretme ve öğrenme yaklaşımıdır (Öztürk vd., 2021). Bu nedenle kültürel miras eğitimi, insanların kültürel miraslarını içeren değerler ve olaylara ilişkin farkındalığını artırır (Hunter, 1992). Kültürel miras eğitiminin amac1, bireylerin tarihi yerler ve ögeler hakkında bilgilenmelerini sağlayarak tarihi unsurlar ve gelenekler üzerinde bir muhafaza duygusu aşılarken bununla ilintili olarak bu mirasın korunmasında aktif olarak sorumluluk hissettirmektir (Copeland, 2004). Mirasın inşası, yorumlanması ve korunmasında sadece hükümetler değil, toplum da sorumludur. Turizm bağlamında düşünüldüğünde, turistlerin gittikleri bölgede somut veya somut olmayan kültürel mirası aktarma, yorumlama ve koruma işi görevi turist rehberlerine düşmektedir. Bu nedenle turist rehberliği eğitiminde kültürel mirasla ilgili derslerin bulunmas1 gerekmektedir (Therond, 2009)

Turist rehberliği eğitimi ile ilgili yapılmış çalışmalar ele alındığında Değirmencioğlu (1998) turist rehberliği eğitiminin yükseköğretim düzeyinde verilmeye başlaması ile turist rehberliği bölümlerinin müfredatlarını eleştirel bir yaklaşım ile değerlendirmiş ve farklı ülkelerdeki turist rehberliği programlarını da incelemiştir. İşçeli \& Kılıç (2018) lisans düzeyinde turizm rehberliği eğitimi veren fakültelerin müfredatlarını incelemiş, bölümlerdeki dersleri zorunlu ve seçmeli kategorilerinde değerlendirerek ilgili bölümlerin akademik kadrolarını da unvanlarına göre sınıflandırmıştır. Yenipınar \& Zorkirişçi (2016) ise Türkiye'de günümüz turist rehberliği eğitimini Avrupa Birliği ülkeleri ile karşılaştırmasını yapmaktadır. Çalışmada turizm rehberliği bölümlerinde mesleki teknik derslerin eksikliğine dikkat çekilmekte, uygulama ağılıklı derslerin arttırılması gerekliliğine vurgu yapılmaktadır. Eker \& Zengin (2016) de turist rehberlerinin eğitim müfredatlarına ilişkin görüş ve tespitlerine yer verdikleri çalışmada, bölümlerin ders programlarının kurumlar arası farklılık göstererek belirli bir standartta olmaması rehberlik eğitimini olumsuz etkilediğini bildirerek programlarda rehberlik mesleği ile yakından ilişkisi bulunmayan derslerin fazlalığına dikkat çekmektedir. İstanbullu Dinçer \& Çakmak (2018) turist rehberliği bölümlerinin müfredatlarını Türk kimliği açısından ele almış ve içinde Türk kimliği ile ilgili bilgiler yer alan dersleri incelemiştir.

\section{Araştırmanın Amacı ve Önemi}

Kültürel mirasın somut ve somut olmayan unsurları turist rehberliği mesleğinin en önemli anlatım konularını oluşturmaktadır. Turistlerin özellikle kültür turlarına katılmalarında öncelikli amaç farklı kültürleri tanımak ve anlamaktır. Bu da ancak turiste destinasyonun kültürünün en iyi şekilde tanıtılması ile mümkün olacaktır. Turist rehberleri yerel kültürel miras1, yaşayan kültürü ve bir destinasyonun kültürel kimliğini öğretir ve yorumlar (Yu et al., 2002). Turist rehberleri mesleklerinin bir gereği olarak kültürel değerleri koruma ve yaşatma misyonuna sahip çıkma çabasındadır. Turist rehberlerinin gerçekleştirdiği kültürel bilgi ve deneyim aktarımları, turistlerin kültürel değerlere karşı daha hassas tutumlar sergilemesini sağlayabilmektedir (Ar \& Çelik Uğuz, 2015). Bu doğrultuda turistle birebir iletişimde olup ülkelerinin kültürel ve doğal çekiciliklerini onlara aktaran turist rehberlerinin eğitimi gerek nitelikli rehber yetiştirilmesinde gerekse bu rehberlerin ülkenin imajının oluşumunda etkisi oldukça önemlidir. Turist rehberliği eğitiminde turist rehberinin sorumlulukları göz önünde tutulduğunda kültürel miras eğitiminin yeri oldukça önemli görülmektedir.

Özsoy ve Çokal; Kültürel Miras Eğitimi Açısından Turizm Rehberliği Bölümlerine Yönelik Müfredat İncelemesi/ Examination on the Curriculum of Tourism Guidance Departments within the Scope of Cultural Heritage Education 
Çalışmanın amacı turist rehberliği programları müfredatlarında kültürel miras eğitiminin incelenmesidir. Bu inceleme kapsamında, kültürel miras eğitiminin verilme oranı, veriliyorsa bu hangi dersler aracılığ ile verilmekte ve derslerin kredilerinin turist rehberliği eğitimi için yeterli olup olmadığının tespit edilmesi amaçlanmaktadır. Turist rehberlerinin ülkelerinin kültür elçisi konumunda olduğu dikkate alındığında kültürel miras eğitiminin rehberlik eğitiminde önemli bir payı olması beklenmektedir. Turist rehberleri bir toplumun sahip olduğu tüm değerleri ile var olan kültürel mirasın yaşatılmasına, korunmasına ve evrenselleşmesine katkı sağlayan birer miras yorumcusu olarak büyük öneme sahiptir. Aynı şekilde kültürel miras unsurları da turist rehberlerinin gerek anlatımlarında gerekse meslek hayatlarında en önemli sunum kaynaklarını oluşturmaktadır (Çokal, 2020). Bu nedenle kültürel miras eğitiminin de benzer öneme sahip olduğu düşünülmektedir. Bu çalışma, turist rehberliği eğitimi veren kurumların kültürel miras eğitiminde varsa eksikliklerinin ortaya koyularak farkındalık oluşturması açısından önem arz etmektedir.

\section{Yöntem}

Araştırmada turizm rehberliği bölümlerinin müfredat incelenmesi gerçekleştirilmiştir. Nitel araştırma yöntemleri ile gerçekleştirilen araştırmada içerik analizi yöntemi kullanılmış olup bu amaçla Türkiye'de lisans düzeyinde turizm rehberliği eğitimi veren yükseköğretim kurumlarının müfredatları incelenmiştir. İçerik analizi, araştırılan alanda sınıflandırma yaparak veya ana bileşenlerin özetlenerek bir takım çıkarımlarda bulunmak suretiyle geleceğe yön veren bilimsel bir tekniktir (Suri \& Clarke, 2009). Elde edilmek istenen sonuçlar mesajın kendisi ile ilgili olabildiği gibi, mesajı gönderen kişi veya mesajın muhatapları ile de ilgili olabilir (Weber, 1990). İçerik analizi yöntemini uygulayabilmek için metinlerin kodlanması veya yönetilebilecek şekilde kategorilere ayrılması gerekmektedir (Leblebici \& Kılıç, 2004). Bu kapsamda öncelikle Yök Lisans Atlası incelenerek lisans düzeyinde turizm rehberliği eğitimi veren yükseköğretim kurumları tespit edilmiştir (YÖK Lisans Atlası, 2021). Daha sonra bu bölümlerin internet sayfaları incelenerek müfredatlarında kültürel mirasa ilişkin derslerinin olup olmadığ 1 ve miras kavramı ile ilişkili hangi derslerin müfredatlarında yer aldığı tespit edilmeye çalışılmıştır. Bu aşamada yalnızca "kültürel miras" kavramı değil ilişskili olan " miras" kavramı da müfredatlarda incelenmeye alınmıştır. Ayrıca çalışmada vakıf üniversiteleri ile devlet üniversitelerinin müfredatları da karşılaştırılarak analiz edilmiştir. Ancak bazı bölümlerin müfredatlarına ulaşılamamış, kurumlardan bilgi talep edilmiş ancak geri dönüş alınamamıştır. $\mathrm{Bu}$ nedenle, bu üniversiteler ve bölümleri çalışmada "ulaşılamamıştır" şeklinde belirtilmiştir.

Çalışma yükseköğretim kurumlarında lisans düzeyinde eğitim vermekte olan turizm rehberliği, turist rehberliği ve seyahat işletmeciliği ve turist rehberliği programlarının müfredatları incelenerek gerçekleştirilmiştir. Meslek yüksekokullarında yer alan önlisans düzeyinde turist rehberliği ve lisansüstü düzeyde turizm rehberliği eğitimi veren programların müfredatları çalışma sınırları dışında bırakılmıştır.

\section{Bulgular}

Turist rehberliği eğitimi geleceğin kültür elçilerini yetiştirme ve gelişimlerine katk1 sağlama açısından oldukça önem arz etmektedir. Bu kısımda lisans düzeyinde turizm rehberliği eğitimi veren üniversitelerin müfredatında bulunan kültürel miras derslerine ilişin tespitler yer almaktadır. Bu kapsamda lisans düzeyinde turizm rehberliği programlarında yer alan derslerin seçimlik durumu, derslerin işlendiği dönemler ve ders isimlerine göre kategorilendirmeye gidilerek müfredatlar incelenmiş ve tablolaştırılmışıtır. Tablo 2'de lisans düzeyinde turizm rehberliği eğitimi veren kurumların kültürel miras eğitimine ilişkin verileri yer almaktadır.

Özsoy ve Çokal; Kültürel Miras Eğitimi Açısından Turizm Rehberliği Bölümlerine Yönelik Müfredat İncelemesi/ Examination on the Curriculum of Tourism Guidance Departments within the Scope of Cultural Heritage Education 
Turist Rehberliği Dergisi (TURED) \& Yıl. 2021, Cilt. 4, Sayı. 2

Journal of Tour Guiding (JOTOG) \& Year. 2021, Volume. 4, Issue. 2

Tablo 2

Turizm Rehberliği Programlarının Ders Müfredatlarında Kültürel Miras Eğitiminin Oranı

\begin{tabular}{ccc}
\hline Kurum & $\mathbf{n}$ & $\mathbf{\%}$ \\
\hline Kültürel Miras Eğitimine İlişkin & 16 & 42,10 \\
Ders Olan Kurumlar & & 47,37 \\
Kültürel Miras Eğitimine İlişkin & 18 & 10,53 \\
Ders Olmayan Kurumlar & 4 & 100 \\
\hline Ulaşlamayan & 38 &
\end{tabular}

Tablo 2 incelendiğinde lisans düzeyinde turizm rehberliği eğitimi veren 38 kurumun yalnızca \%42,10 (n:16)'unda kültürel miras eğitimine yönelik dersler bulunduğu görülmektedir. $\mathrm{Bu}$ da yaklaşık yarısında kültürel miras eğitimi olmadığını göstermektedir. Doğal ve kültürel mirasın korunmasında ve aktarılmasında oldukça önemli rolü olan turist rehberlerinin eğitimleri süresince bu derslerden uzak kalmaları oldukça dikkat çekici bir bulgudur. Sonrasında çalışma kapsamında vakıf üniversiteleri ile devlet üniversitelerinin müfredatları kültürel miras eğitimi açısından karşılaştırılmış ve Tablo 3 'de verilmiştir.

Tablo 3

Kültürel Miras Eğitiminin Vakıf ve Devlet Üniversitelerinde Karşılaştırılması

\begin{tabular}{ccccc}
\hline Kurum & \multicolumn{2}{c}{ Devlet } & \multicolumn{2}{c}{ Vakıf } \\
\cline { 2 - 5 } & $\mathbf{n}$ & $\mathbf{\%}$ & $\mathbf{n}$ & $\mathbf{\%}$ \\
\hline $\begin{array}{c}\text { Kültürel Miras Eğ̈itimine İlişkin Ders Olan } \\
\text { Kurumlar }\end{array}$ & 15 & 39,37 & 1 & 2,63 \\
$\begin{array}{c}\text { Kültürel Miras Eğitimine İlişkin Ders Olmayan } \\
\quad \begin{array}{l}\text { Kurumlar } \\
\text { Ulaşılamayan }\end{array}\end{array}$ & 16 & 42,10 & 2 & 5,37 \\
\hline Toplam & 4 & 10,53 & - & - \\
\hline
\end{tabular}

Devlet ve vakıf üniversitelerinin karşılaştırıldığı Tablo 3'e bakıldığında, turizm rehberliği eğitimi veren 3 vakıf üniversitesinden yalnızca 1'inin müfredatında kültürel miras eğitimine ilişkin dersler olduğu diğer 2 kurumda buna yönelik verinin olmadığ 1 tespit edilmiştir. Benzer şekilde devlet üniversitelerinin ilgili bölümlerinde kültürel miras eğitimine ilişkin dersler incelendiğinde, birbirine yakın bir oran (Olan \%39,37; Olmayan: \%42,10) görülmekte, bu dersin 15 kurumda bulunduğu, 16'sında ise bulunmadığı tespit edilmiştir. Turizm rehberliği eğitimi veren kurumların 4'ünde müfredat bilgisine ulaşılamamıștır. Geriye kalan 34 kurumdan yalnızca 16'sında kültürel miras kapsamında dersler verilmektedir. Mevcut müfredatlarında kültürel miras eğitimine ilişkin dersler bulunan kurumlar incelendiğinde Tablo 4'deki gibi bir ders kategorilendirilmesi yapılmıştır. 
Turist Rehberliği Dergisi (TURED) \& Yıl. 2021, Cilt. 4, Sayı. 2

Journal of Tour Guiding (JOTOG) \& Year. 2021, Volume. 4, Issue. 2

Tablo 4

Kültürel Miras Eğitimine İlişkin Derslerin İsimlerine Göre Kategorilendirilmesi

\begin{tabular}{ccc}
\hline \multirow{2}{*}{ Ders adı } & \multicolumn{2}{c}{ Verildiği Kurum Sayısı } \\
\cline { 2 - 3 } & $\mathbf{n}$ & $\mathbf{\%}$ \\
\hline Kültürel Miras & 3 & 18,75 \\
Kültürel Miras Turizmi & 2 & 12,5 \\
Kültürel Miras ve Turizm & 1 & 6,25 \\
Kültürel Miras Yönetimi & 3 & 18,75 \\
Kültür Turizmi ve Dünya Külttürel & 4 & 25,0 \\
Mirası & 1 & 6,25 \\
Kültürel Miras Anlatımı & 1 & 6,25 \\
Dünya Miras Alanları & 1 & 6,25 \\
Endüstriyel Miras Turizmi & 16 & 100 \\
\hline Toplam & &
\end{tabular}

Kültürel miras kapsamında müfredatta yer alan ders isimlerine göre bir kategori oluşturulmuştur. Bu kategorilendirmeye göre turizm rehberliği bölümlerinde en fazla (\% 25) "kültür turizmi ve dünya kültürel mirası" isimli ders olduğu bununla birlikte kültürel miras ile bağlantılı 8 farklı ders isminin yer aldığı görülmektedir. Derslerin benzer isimlere sahip olduğu ancak birebir aynı olmadığ 1 tespit edilmiştir. Tablo 5'de müfredatta yer alan kültürel miras kapsamındaki derslerin saatlerine ve seçmeli/zorunlu olma durumlarına ilişkin veriler yer almaktadir.

Tablo 5

Ders saatleri ve Derslerin Seçmeli/ Zorunlu Olma Durumları

\begin{tabular}{cccccc}
\hline \multirow{2}{*}{ Kurum } & \multicolumn{2}{c}{ 2 Saat } & \multicolumn{3}{c}{ 3 saat } \\
\cline { 2 - 6 } & $\mathbf{n}$ & $\mathbf{\%}$ & $\mathbf{n}$ & $\mathbf{\%}$ \\
\hline Zorunlu Dersler & 3 & & 18,75 & 3 & 18,75 \\
Seçmeli Dersler & 9 & & 56,25 & 1 & 6,25 \\
\hline Toplam & & 16 & & & 100 \\
\hline
\end{tabular}

Lisans düzeyinde turizm rehberliği eğitimi veren kurumların müfredatlarında yer alan kültürel miras odaklı derslerin seçmeli ve zorunlu olma durumu ele alındığında büyük oranda (n:10) seçmeli ders kategorisinde yer aldığ 1 tespit edilmiştir. Bununla birlikte ders saatleri incelendiğinde 2 (n:12) ve 3 (n:4) saat olarak müfredatlarda yer aldığ 1 tespit edilmiştir.

Tüm bulgular birlikte değerlendirildiğinde kültürel mirasa ilişkin derslerin müfredatlarda yeterli sayıda ve saatte olmadığı görülmektedir. Bununla birlikte müfredatlar arasında da uyum olmadığı her kurumun kendine göre farklı bir isimle dersi adlandırdığı görülmektedir.

\section{Sonuç ve Öneriler}

Farklı kültürleri tanıma ve deneyimleme isteğinde olan turistler bu amaçla seyahate çıkmaktadır. Bu seyahatlerinde kültürü deneyimlemesine ve öğrenmesine yardımcı olan turizm hizmet sağlayıcılarıdır. Özellikle turistlerle birebir iletişimde olarak destinasyondaki kültürel mirasın aktarılmasında ve tanıtılmasında en önemli role sahip olan kişi turist rehberidir. Turist rehberleri, turistlerin tur boyunca deneyimlerinin artması aynı zamanda destinasyonların ve 
bölge kültürünün kavranması konusunda hayati bir rol oynamaktadır (Gelbman \& Maoz, 2012). Turistlere, cazibe merkezlerinde neleri gözlemleyip nelere dikkat etmeleri gerektiğini ve daha da önemlisi, gördüklerini nasıl yorumlayacaklarını söyleyerek bakış açılarını yönlendirir (Urry, 1990).

Turist rehberinin miras yorumlayıcı ve kültürel mirasın aktarımındaki rolü dikkate alındığında bu konuda bilgi birikiminin önemli olduğu görülmektedir. Bu da iyi bir eğitimle mümkün olmaktadır. İyi bir rehberlik eğitimi, kaliteli rehberler yetişmesine, kaliteli rehberlerin eşlik ettikleri grubun ziyaretlerinden memnun kalmasına, tatillerinden mutlu ayrılan turistler olumlu ülke imajına, bir ülkenin turizmdeki imajının olumlu yönde gelişmesi turizmden aldığı payın artmasına ve dolayısıyla rekabet üstünlüğü elde etmesine imkân tanıyacaktır (Eker \& Zengin, 2016). Birer kültür elçisi olan turist rehberleri kültürel mirasın korunması, yaşatılması ve aktarılmasında da kilit rol üstlenmektedir (Köroğlu vd., 2018).

Tüm bunların 1şığında bu çalışma ile turist rehberliği eğitiminde kültürel mirasın yeri tespit edilmeye çalışlmıştır. Türkiye'de lisans düzeyinde turizm rehberliği eğitimi veren müfredatları doküman inceleme tekniği ile incelenmiş ve kültürel miras eğitimine ilişkin bulgular ortaya koyulmaya çalışılmıştır. Yapılan incelemeler sonucunda lisans düzeyinde turizm rehberliği eğitimi veren 38 kurum olduğu, bu kurumların yalnızca $16(\% 42,10)$ tanesinde kültürel mirasa ilişkin dersler olduğu görülmüştür. Bununla birlikte verilen bu derslerin çoğunun (\%63) seçmeli ders kategorisinde ve 2 saat (\%75) olduğu bulgusuna ulaşılmıştır. Bir diğer tespit edilen durum ise kültürel mirasa ilişkin derslerin benzer konular çerçevesinde farklı isimlerle yer alıyor olmasidır.

Turist rehberleri kültür elçisi konumunda olan; kültürel mirasın aktarılmasında, tanıtılmasında ve kültürlerarası iletişimde önemli role sahip olan kişilerdir (Çokal, 2015). Turist rehberlerine bu rolleri atfederken aktarmaları beklenen kültürel mirasa ilişkin eğitimin yeterince verilememesi önemli bir eksik olarak görülmektedir. Turist rehberliği mesleğinin sermayesi konumunda olan kültürel miras iyi bir eğitimle bilgi birikimi kazanılabilecek bir konudur. Bunun için de turist rehberliği bölümlerinde yeterli oranda derslerin yer alması gerekmektedir.

$\mathrm{Bu}$ çalışma ile turist rehberliği eğitiminde kültürel miras eğitiminin yeri tespit edilmeye çalışılmış ve eksiklikler ortaya koyulmuştur. Bu kapsamda lisans düzeyinde turizm rehberliği eğitimi veren kurumların müfredatlarında kültürel mirasa ilişkin ders eksikliklerini gidermesi ve tüm kurumların ortak müfredat geliştirmesi önerilmektedir. Geliştirilen bu ortak müfredatta ders içerikleriniz birbirine yakın olmasına dikkat edilmelidir. Turizm rehberliği eğitiminin temel problemlerinden biri olan müfredat farklılığı kültürel miras eğitimi kapsamında ele alındığında da dikkat çekmektedir.

Eğitimin etkinliğini arttırması amacıyla, teorik olarak sunulan kültürel miras dersi kapsamında zaman zaman sahaya inilmesi ve müze, ören yeri, dini ve sanatsal yapılar gibi kültürel miras açısından değerli turistik önemi bulunan unsurlara ziyaretler gerçekleştirilmelidir. Derslerin yanı sıra kültürel miras unsurlarına ilişkin üniversitelerde konferans, panel, seminer gibi programlar gerçekleştirilmelidir. Buna ilaveten, her bir Somut ve Somut Olmayan Kültürel Miras unsurlarına ilişkin dersler imkan dahilinde müfredata eklenebilir.

Gelecek çalışmalarda kültürel miras eğitimine ilişkin gerek akademisyenlerin gerekse turist rehberlerinin görüşleri değerlendirilerek kültürel miras eğitimine yönelik bir değerlendirme yapılabilir. Bununla birlikte turist rehberliği eğitiminde yer alması gereken diğer temel konulara ilişkin de müfredat incelemesi yapılması eksikliklerin tespiti için önemli görülmektedir. Kültürel miras dersi kapsamında yüksek lisans ve doktora programlarının müfredatları da incelenebilir. Bu ders müfredatları sadece isim olarak değil içerik olarak da incelenebilir ve buna yönelik bulgular ilave edilebilir. 


\section{Kaynakça}

Ap, J., \& Wong, K. K. (2001). Case study on tour guiding: Professionalism, issues and problems. Tourism Management, 22(5), 551-563.

Albrecht, J. N., Moscardo, G., \& Dwyer, T. (2021). Learning about learning in tourism: indigenous guide perspectives on their personal and professional development. Journal of Hospitality \& Tourism Research, doi:10.1177/1096348021997535

Ar, H., \& Çelik Uğuz, S. (2015). Somut olmayan kültürel mirasın korunmasında turist rehberlerinin rollerine yönelik turist algıları üzerine bir araştırma. Journal of International Social Research, 8(41), 1406-1418.

Cohen, E. (1985). The tourist guide: The origins, structure and dynamics of a role. Annals of Tourism Research, 12(1), 5-29.

Copeland, B. J. (Ed.). (2004). The essential turing. Clarendon Press.

Çokal, Z. (2015). Bir kültür elçisi olarak profesyonel turist rehberinin turistlere aktarllan kültürel değerlere katklsına yönelik turist algılamaları: Nevşehir örneği. (Tez No. 407276) [Yüksek Lisans Tezi, Nevşehir Hacı Bektaş Veli Üniversitesi]. YÖK Tez Merkezi, https://tez.yok.gov.tr/UlusalTezMerkezi/tezSorguSonucYeni.jsp

Çokal, Z. (2020). Tourist Guiding in The Transmission of Cultural Heritage, (Ed.): Türkmen, F.: Cultural Heritage and Tourism, Berlin: Peter Lang.

Demir, M., Pelit, E., \& Türkoğlu, T. (2018). Kültürel mirasın sürdürülebilirliği: Turizm eğitimi veren kurum müfredatları üzerine bir inceleme. Turizm Akademik Dergisi, 5(2), 73-83.

Eker, N., \& Zengin, B. (2016). Turist rehberliği eğitiminin değerlendirilmesi: Profesyonel turist rehberleri üzerine bir uygulama. Ĕgitim ve Ögrretim Araştırmaları Dergisi, 5(4), 6574.

FEG (2021). Turist rehberliği. European Federation of Tourist Guide Associations. Erişim tarihi: Kasım 5. 2021. https://www.feg-touristguides.com/about.php.

Gelbman, A., \& Maoz, D. (2012). Island of peace or island of war: Tourist guiding. Annals of Tourism Research, 39(1), 108-133.

Greiner, R., \& Wegner, A. (2014). Industry leadership in tourist guiding: A member's perspective of SGL using the organisational learning framework. Asia-Pacific Journal of Innovation in Hospitality and Tourism (APJIHT), 1(3), 1-13.

Hunter, K. (1992). Heritage education: What's going on out there?. In Paper presented at the 107th annual meeting of the American Historical Association. Washington, DC: American Historical Association.

Köroğlu, Ö., Yıldırım, H. U., \& Avcıkurt, C. (2018). Kültürel miras kavramına ilişkin algıların metafor analizi yoluyla incelenmesi. Turizm Akademik Dergisi, 5(1), 98-113.

Kuşluvan, S., \& Çeşmeci, N. (2002). Türkiye'de turist rehberliği ĕgitiminin sorunları ve yeniden yapılandırılması. Turizm Eğitimi Konferansı, 11-13 Aralık 2002, Turizm Bakanlığı, Turizm Eğitim Genel Müdürlüğ̈̈, Ankara.

Kuter, N., \& Ünal, H. E. (2009). Sürdürülebilirlik kapsamında ekoturizmin çevresel, ekonomik ve sosyo-kültürel etkileri. Kastamonu Üniversitesi Orman Fakültesi Dergisi, 9(2), 146156.

Kültür ve Turizm Bakanlığı, (2009). Kültürel Miras ve Müzecilik. Erişim tarihi: Kasım 15, 2021 https://teftis.ktb.gov.tr/Eklenti/1279,muserrefcanpdf.pdf?0

Kültür ve Turizm Bakanlığı, (2021). UNESCO Kültürel Miras Listesi. Erişim tarihi: Kasım 15, 2021 https://www.ktb.gov.tr/TR-96283/kulturel-miras.html

Leblebici, D. N., \& Kılıç, M., (2004). İ̧̧erik analizi. Ankara: Hacettepe Üniversitesi İ.İ.B.F. Yayınları. 
Leclerc, D., \& Martin, J. N. (2004). Tour guide communication competence: French, German and American tourists' perceptions. International Journal of Intercultural Relations, 28(34), 181-200.

Lugosi, P., \& Bray, J. (2008). Tour guiding, organisational culture and learning: Lessons from an entrepreneurial company. International Journal of Tourism Research, 10(5), 467-479.

Nişancı, Z. N. (2012). Toplumsal kültür-örgüt kültürü ilişkisi ve yönetimi üzerine yansımaları. Journal of Life Sciences, 1(1), 1279-1293.

Ölçer Özünel, E. (2013). Yeni Miraslar ve uluslararası sözleşmelerde sürdürülebilir kalkınma stratejileri. Milli Folklor, 25(100), 14-30.

Özkök, F., \& Gümüş, F. (2009). Sürdürülebilir turizmde bilginin önemi. Yönetim Bilimleri Dergisi, 7(1), 51-71.

Öztürk, H. M., Güngör, H., \& Ogelman, H. G. (2021). Okul öncesi dönemde kültürel miras eğitimine ilişkin öğretmen görüşleri: Denizli ili örneği. Güncel Turizm Araştırmaları Dergisi, 5(1), 175-203.

Steiner, C. J., \& Reisinger, Y. (2006). Understanding existential authenticity. Annals of Tourism Research, 33(2), 299-318.

Suri, H., \& Clarke, D. (2009). Advancements in research synthesis methods: From a methodologically inclusive perspective. Review of Educational Research, 79(1), 395-430.

Şimşek, G. (2014). Kültürel miras ve yeni biçimlenme süreci üzerine bir değerlendirme. 21. Yüzyllda Eğitim ve Toplum Eğitim Bilimleri ve Sosyal Araştırmalar Dergisi, 3(8), 67-92.

Tekin, Ö., Bideci, M., \& Aydın, A. (2015). Kültürel mirasın aktarımında mobil rehber uygulamaları ile profesyonel turist rehberlerinin yetkinliğinin karşılaştırması (Konya Mevlana Müzesi örneği). I. In Eurasia International Tourism Congress: Current Issues, Trends, and Indicators (EITOC-2015) (pp. 679-686).

Thérond, D. (2009). Benefits and innovations of the Council of Europe Framework Convention on the Value of Cultural Heritage for Society. Heritage and Beyond, 9-11.

TUREB (2021). Resmi rehber istatistikleri. Turist Rehberler Birliği. Erişim tarihi: Kasım 10, $2021 \mathrm{http}: / /$ tureb.org.tr/tr/RehberIstatistik/.

TUREB (2021). Turist rehberliği eğitimi. Turist Rehberler Birliği. Erişim tarihi: Kasım 6, $2021 \mathrm{http}: / / \mathrm{www}$. tureb.org.tr/tr/Page/Detail/60.

Urry, J. (1990). The consumption' of tourism. Sociology, 24(1), 23-35.

Weber, P. W., (1990). Basic content analysis. (2nd ed.) Sage Publications.

YÖK Lisans Atlası (2021). Turizm Rehberliği programları. Yüksek Öğretim Kurumu Lisans Atlası. Erişim tarihi: Kasım 6. 2021 https://yokatlas.yok.gov.tr/lisans-anasayfa.php.

Yu, X., \& Ham, S. (2004). Cultural mediation in guided tour experiences: A case study of Australian guides of Chinese tour groups. Department of Management Working Paper Series, 44, 1-12. 
Turist Rehberliği Dergisi (TURED) \& Yıl. 2021, Cilt. 4, Sayı. 2

Journal of Tour Guiding (JOTOG) \& Year. 2021, Volume. 4, Issue. 2

\section{ETIK ve BILLIMSEL İLKELER SORUMLULUK BEYANI}

Bu çalışmanın tüm hazırlanma süreçlerinde (veri toplama, yazım vb.), tüm etik kurallara ve bilimsel atıf gösterme ilkelerine riayet edildiğini, herhangi bir hataya mahal vermemek için yayımdan önce makalenin bir intihal programı aracılığıyla da kontrol edildiğini yazarlar beyan eder. Ayrıca yazarlar aşağıda sıralanan hususları kabul etmiştir:

1. Calıșmada yer alan ve kullanılan tüm kaynaklara, bilimsel araștırma yöntemleri ve etik ilkeler doğrultusunda atıf yapılmıştır

2. Çalışmada tüm yazarların akademik-bilimsel olarak doğrudan ve ortak katkısı vardır.

3. Bu çalışma, yazarların özgün bir çalıșmasıdır.

4. Bütün yazarlar dergiye gönderilen makaleyi görmüș ve sonuçlarını onaylamıștır.

5. Çalışmada kullanılan denek/deneklere ilişkin herhangi bir etik ihlal yapılmamış, kullanılan tüm veri toplama yöntemlerinde bilimsel etik ilkelere göre hareket edilmiștir.

6. Çalışma daha önceden bilimsel bir toplantıda sunulan özet veya bu çalışmanın daha kısa hali ise, makalede bu durum belirtilmiștir.

7. Çalıșmada, hiçbir suç unsuru veya kanuna aykırı ifade bulunmamakla birlikte, araştırma yapılırken kanuna aykırı herhangi bir yöntem kullanılmamış olup, çalışma ile ilgili tüm yasal izinler alınmış ve etik kurallara uygun hareket edilmiştir.

Aksi bir durumun tespiti halinde Turist Rehberliği Dergisi’nin hiçbir sorumluluğu olmayıp, tüm sorumluluk makale yazarlarına aittir.

Tarih : :05/12/2021

Sorumlu Yazar : : Aybüke ÖZSOY 